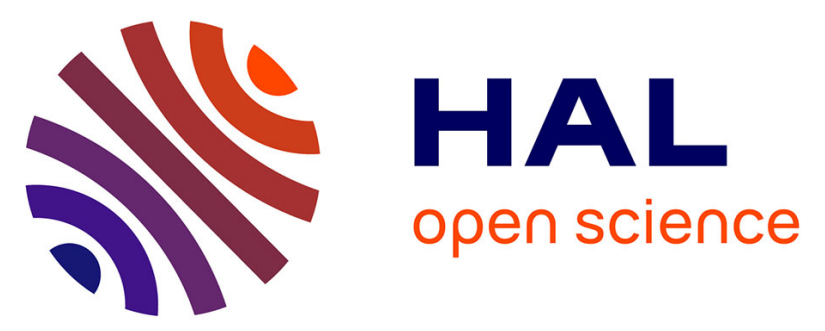

\title{
Retail decline in France's small and medium-sized cities over four decades. Evidences from a multi-level analysis
} Matthieu Delage, Sophie Baudet-Michel, Sylvie Fol, Sophie Buhnik, Hadrien Commenges, Julie Vallée

\section{- To cite this version:}

Matthieu Delage, Sophie Baudet-Michel, Sylvie Fol, Sophie Buhnik, Hadrien Commenges, et al.. Retail decline in France's small and medium-sized cities over four decades. Evidences from a multilevel analysis. Cities, 2020, 104, pp.102790. 10.1016/j.cities.2020.102790 . halshs-02617016

\section{HAL Id: halshs-02617016 \\ https://shs.hal.science/halshs-02617016}

Submitted on 9 Jun 2020

HAL is a multi-disciplinary open access archive for the deposit and dissemination of scientific research documents, whether they are published or not. The documents may come from teaching and research institutions in France or abroad, or from public or private research centers.
L'archive ouverte pluridisciplinaire HAL, est destinée au dépôt et à la diffusion de documents scientifiques de niveau recherche, publiés ou non, émanant des établissements d'enseignement et de recherche français ou étrangers, des laboratoires publics ou privés. 


\title{
Retail Decline in France's Small and Medium-Sized Cities over four decades. EVIDENCES from a Multi-LeVel ANAlysis.
}

\author{
Matthieu Delage ${ }^{1}$, Sophie Baudet-Michel ${ }^{2}$, Sylvie Fol $^{3}$, \\ Sophie Buhnik ${ }^{4}$, Hadrien Commenges ${ }^{5}$, Julie Vallée ${ }^{6}$
}

\begin{abstract}
${ }^{1}$ UNIVERSITE GUSTAVE EIFFEL, Laboratoire de recherche « Analyse Comparée des Pouvoirs », EA 3350, ACP - Bois de l'Étang, 5, Boulevard Descartes, 77454 Marne-la-Vallée Cedex 2, France.

Matthieu.delage@u-pem.fr

${ }^{2}$ UNIVERSITE DENIS DIDEROT, UMR 8504 Géographie-cités, Bâtiment de recherches sud, Campus Condorcet, 5, cours des Humanités, 93322 Aubervilliers, France

sophie.baudet-michel@univ-paris-diderot.fr

3 UNIVERSITE PARIS 1 PANTHEON-SORBONNE, UMR 8504 Géographie-cités, Bâtiment de recherches sud, Campus Condorcet, 5, cours des Humanités, 93322 Aubervilliers, France

$\underline{\text { Sylvie.Fol@univ-paris1.fr }}$

Sophie BUHNIK ${ }^{4}$

${ }^{4}$ Institut français de recherche sur le Japon (CNRS-MEAE), Maison franco-japonaise, 3-9-25 Ebisu, Shibuya-ku, Tokyo 150-0013, JAPAN.

sophie.buhnik@gmail.com

${ }^{5}$ UNIVERSITE PARIS 1 PANTHEON-SORBONNE, UMR 8504 Géographie-cités, Bâtiment de recherches sud, Campus Condorcet, 5, cours des Humanités, 93322 Aubervilliers, France hadrien.commenges@univ-paris1.fr

${ }^{6}$ CNRS, UMR 8504 Géographie-cités, UMR 8504 Géographie-cités, Bâtiment de recherches sud, Campus Condorcet, 5, cours des Humanités, 93322 Aubervilliers, France julie.vallee@parisgeo.cnrs.fr
\end{abstract}

\begin{abstract}
In recent years, a vast array of literature has shown that more and more city centres are affected by retail decline, be it in Japan, Belgium, Britain, the United States, or in France, while urban peripheries benefit from expanding retail activities. In this paper, we first rely on an international state of the art review, which allows us to identify recurring main factors that explain retail decline (such as sectoral concentration and competition from e-commerce), as well as more contextual factors bringing changes in urban settings and consumption practices (like demographic and labour market dynamics, the size of cities, or the location of municipalities within cities). Secondly, we examine how these factors, when combined, contribute to explain the decline in a superior diversity mix of retail activities in small and medium-sized French towns and cities, for four periods of about ten years each, from 1975 to 2014. The decline in shop diversity affects about a third of the municipalities observed in each period. Our hypotheses regarding the role of demographic size, employment mobility and location are then discussed and compared with the information given by the literature review.
\end{abstract}

Keywords: Retail; Superior retail mix; Municipalities; Small and Medium-sized Cities; Decline; Factors of Decline 


\section{1- Introduction}

In recent years, the decline of retailing in urban centres and high streets has been observed in many countries e.g. Great Britain (Portas, 2011; Hallsworth \& Coca-Stefaniak, 2018), Belgium (Grimmeau \& Wayens, 2016), France (Madry, 2016), North America (Rao \& Summers, 2016; Kickert \& Vom Hofe, 2018) or Japan (Arata, 2012; Kudo, Kimura, Nozaki, \& Ueda, 2012; Katayama, Kawasaki \& Taniguchi, 2019). It is reflected in particular by the fall in the number of shops, the decrease in the diversity of supply and the increase in shop vacancies. ${ }^{1}$ These changes are primarily explained by specific mutations in the retail sector, as the share of independent outlets falls to the benefit of major retailers (Donofrio, 2008; Hallsworth \& Coca-Stefaniak, 2018), and, more recently, as e-commerce has developed (Singleton et al., 2016; Lee et al., 2017). They also result from the geographical redistribution of retailing space, which is increasingly located in peripheral areas, in line with the growth of large suburban shopping centres (Kickert \& Vom Hofe, 2018).

In France, Belgium, Japan, Great Britain and the United States in particular ${ }^{2}$, the phenomenon of retail decline in urban centres has been particularly pronounced in small and medium-sized cities, whereas large cities are marked more by a return to centres and constitute areas of consumption and leisure sought after by urban populations. There is thus a growing gap between metropolitan centres, whose business vitality often goes hand-in-hand with gentrification (Zukin, Kasinitz, \& Chen, 2015) and a diversification of supply, and the centres of smaller cities, many of which are experiencing a decline in the number of shops and in their diversity (Robertson, 1999; Filion \& Hammond, 2008; Hidetoshi \& Koto 2010; IGF-CGEDD, 2016; Iwama 2017; Yakushiji 2017).

In this context, our article aims at understanding the transformations of retail trade in French cities, based on a multi-decade analysis of the evolution of shop diversity at different scales. It aims to describe the extent of retail mix decline, and to connect it with various explanatory factors related to both the geographical location of businesses (city-centre versus peripheral municipalities), the size of the cities, their demographic dynamics (cities with growing or falling populations) and employment (i.e. the relative attractiveness of cities in terms of jobs) and the local characteristics of the retail trade (the presence or not of supermarkets).

\section{2- Retail Decline and Urban Change: an international literature review}

\section{The decline of independent retail outlets, the growth of large retailers and the suburbanisation of retailing}

In recent decades, the number of retail outlets has declined sharply in many countries, albeit the pace and extent of said decline varies widely from one country to another (Buhnik, 2018). This fall mainly affects small-scale retail stores and independent shops. In Belgium for instance, the number of small businesses fell from 370,000 in 1947 to 191,000 in 2015, a drop of $48 \%$. In terms of shopping space, small businesses are now playing a minor role in retail activity, as they represented less than $49 \%$ of the total retailing surface area in 2014, compared with more than $59 \%$ in 2007 (Grimmeau \& Wayens, 2016). These trends are similar to those found internationally, although the intensity and pace of change may vary (Portas, 2011). In Japan, the decline of independent stores started in the 1980s, peaked in 1990-2000 and is continuing today (Arata, 2012; Tsujii, 2013). According to Czinkota and Kotabe (2000), the number of independent shopkeepers employing fewer than 9 people in Japan represented as much as $60 \%$ of the retail sector in 1982 and dipped below $50 \%$ in 1997, and from 1985 to 2000, around 300,000 independent shops shut their doors, a decrease of around $17 \%$.

\footnotetext{
${ }^{1}$ Shop vacancies refer to closed retail premises, whether it is on an ad hoc basis (due to work or a change in retailing activity) or a more durable closure.

${ }^{2}$ We have chosen to focus our literature review on the countries where commercial decline of centers is best documented (Buhnik, 2018).
} 
Meanwhile, the number of franchised convenience stores (nicknamed konbini) had increased from less than 6,000 units in the early 1980s to more than 55,000 in 2017 (Tanaka, 2015).

It points out to the fact that in all the countries covered by our literature review, a shrinkage in the number of establishments has nonetheless been accompanied with a growth in sales, linked to the economic concentration of retailers: small independent shops have been replaced by a smaller number of larger companies. In the USA, in 1996, the ten most important chain stores covered $15 \%$ of consumer expenditure. In 2005, their share totalled about $30 \%$ while retail space continued to grow (Donofrio, 2008). ${ }^{3}$ This concentration is even more blatant in the discount sector (MacGregor, 2011). In Japan, competition with supermarkets has been based on value for money ratios since the 1970s (Kudo et al. 2012) and deepened during the 1990s, when financial crisis and economic recession had negative impacts on the budgets of middle-class households. They were subsequently driven towards hard discount supermarkets, "simpler" general merchandise stores chains (like "no logo" Muji), brands championing fast retailing (like Uniqlo), or small outlets deemed more convenient than the traditional "Mom and Pop's stores", which the highly organized networks of convenience store chains have gradually embodied, like Lawson or Family Mart (Assmann, 2018; Whitelaw, 2018).In the United Kingdom, the food trade is now controlled by four major brands and dominated by supermarkets, which today account for over 97\% of grocery sales (Portas, 2011). The number of department stores (chain department stores) doubled in the 1950s and tripled in the following decade. This trend has increased with the development of discount chains (discount department stores) and the rapid concentration of this sector (Hallsworth \& Coca-Stefaniak, 2018). Between 1982 and 2017, Tesco's share of the grocery sector expanded from less than $9 \%$ to almost $28 \%$. In the $2010 \mathrm{~s}$, the four largest groups (Walmart, Tesco, Sainsbury's and Morrisons) had control over no less than $75 \%$ of national retail trade (Hallsworth \& Coca-Stefaniak, 2018).

The concentration of the retail sector and the transformation of its spatial organisation in favour of supermarkets affiliated to franchised chains, was significantly tied to the suburbanisation of retail outlets, with little regulation from public authorities, depending on the time period considered. In North America, businesses have progressively withdrawn from central neighbourhoods to establish themselves in peripheral locations, in relation to the development of car-based mobilities and infrastructures and the suburbanisation of wealthier households (MacGregor, 2011; Kickert \& Vom Hofe; 2018). By settling in the suburbs, the chain stores that dominate the retail market - especially Walmart and Target - could access to more affordable, mostly unbuilt land. Thanks to the size and design standardisation of their stores (the so-called big boxes), these chains have gained the ability to provide a number and a variety of products to a growing number of motorized households living in the suburbs (Donofrio, 2008). Longer opening hours and wide parking facilities offered to customers have also contributed to their success (MacGregor, 2011; Guimaraes, 2019). In North America as well as in Europe and Japan, the development of the retail giants has also been also attributed to the weakening, if not the abolition, of planning regulations connected to market liberalisation (Hallsworth \& Coca-Stefaniak, 2018; Fernandes \& Chamusca, 2014). In Great Britain, during the 1980s, the outward expansion of shopping centres was explicitely encouraged by local governments to promote competition and reduce commodity prices (Guimaraes, 2016). By the mid-1990s, Britain had given their approval to the opening of about 1,000 superstores (Hallsworth \& Coca-Stefaniak, 2018). In Japan, postwar high growth initially helped tiny outlets to coexist with partially chain-operated stores. Many of them had a fruitful contractual relationship with large manufacturers, who needed to get access to a rising consumer market and overcome a relatively low rate of motorization among Japanese households (Czinkota \& Kotabe, 2000). But independent retailers became more concerned with their survival from the 1970s onwards, and they exerted pressure over the ruling LiberalDemocratic Party (of which they were an important electoral demographic). It led to the enactment

\footnotetext{
${ }^{3}$ In 1960, there were 4 sq. feet of retail surface area per capita in the United States. By 2005, this had risen to 38 sq. feet (Donofrio, 2008).
} 
of the Large-Scale Retail Store Law in 1973, which prevented any new store over 500 square meters to open within the vicinity of an inner-city shopping arcade, without the consent of local shopkeeper associations (Arata, 2012; Tsujii, 2013). Under the influence of national retailers and the USA (who saw the Law as a barrier to imports), the law was relaxed in 1994, then entirely repealed by the Diet in 1998 (Czinkota \& Kotabe, 2000), so that the average annual number of large-store openings went from 200 in the 1980s to 700 in the 1990s. The transformation of shopping centres into financialised real estate investments and products, subject to market fluctuations, is an emerging global trend (Guimaraes, 2019). It is connected with the liberalisation of markets and the growth of powerful and internationalised private groups in the retail sector (Coe, 2004; Boisnier, 2011; Fernandes \& Chamusca, 2014; CGEDD, 2017).

Although most of the literature highlights the negative impact of shopping mall development on small businesses, research has also emphasized positive effects of complementarity rather than competition, that may occur when a supermarket is established in a central or peri-central location. Wrigley, Branson, Murdock and Clarke (2009) for example, have drawn on a study of the evolution of retailing in more than 1,000 small and medium-sized British cities between 2000 and 2006, and showed that the impact of setting up a supermarket on the opening or closing of small businesses depends on the type of shops involved: it is negative on some businesses such as fruit and vegetable sellers, music or video shops, but positive for bakeries and drug and healthy food stores. The authors deduced that there is a certain complementarity between supermarkets and specific small businesses, as supermarkets attract customers, and as consumers will make group trips and purchases in both types of shops (Wrigley \& Lambiri, 2014). Nevertheless, the authors have pointed out that their results show a marked regional dimension: the establishment of a supermarket impacts negatively on a much wider range of small businesses when it takes place outside regions with sustained economic and demographic growth (Wrigley \& Lambiri, 2014) ${ }^{4}$.

The exponential growth of peripheral retailing is probably not unrelated to the increasingly pronounced vacancy phenomena seen in some suburban shopping centres, especially the older ones (Madry, 2013). This has even led to a process of "demalling" (the decommissioning of a mall to another function), which has recently become very strong in North America and is growing in Europe (Guimaraes, 2019). This process is also partly related to the development of e-commerce.

\section{The development of e-commerce}

E-commerce is experiencing exponential growth everywhere, and is considered as the main cause of the decline in physical trade. Studies focusing in North America (Lee, Sener, Mokhtarian, \& Handy, 2017) estimate that online commerce generated nearly $\$ 300$ billion in sales in 2014 , more than double that in 2000. In the United Kingdom, e-commerce accounted for almost half of growth in retail spending between 2003 and 2010 (Portas, 2011), and online shopping accounted for almost $11 \%$ of total expenditures in 2014 (Wrigley \& Lambiri, 2014). The work done by Singleton et al. (2016) shows that e-shopping tripled in the eight years preceding their study, with forecasts of it meeting more than $15 \%$ of purchases at the end of 2015. This rapid expansion is seen as the major cause of changes in the structure of traditional town centres and high streets (Wrigley \& Lambiri, 2014). Several British national chain stores have either closed or diminished their physical stores, while others have developed the use of new technologies with the opening of "click and collect points" or the development of mobile applications (Singleton et al., 2016). The impact of online commerce varies according to the type of business, with media-related businesses (books, music, video) being much more affected because easily digitalized (Wrigley \& Lambiri, 2014; Singleton, Dolega, Riddlesden, \& Longley, 2016; Lee, Sener, Mokhtarian \& Handy, 2017).

\footnotetext{
${ }^{4}$ This commercial decline is linked with others dimensions of urban change, as demographic change in cities. For more information on shrinking cities, see Turok and Mykhnenko (2007), and Martinez-Fernandez, Weyman, Fol, Audirac, Cunningham-Sabot, Wiechmann \& Yahagi, 2016).
} 


\section{The more pronounced decline of small and medium-sized city centres}

These various changes in retailing have affected urban centres in particular. Hallsworth et al. (2018) show that despite public policies to protect the centres (town centre management policies, business improvement districts), ${ }^{5}$ the disappearance of small shops over the last two decades has resulted in the decline of town centres and high streets, particularly in England and Wales. As for the UK, city centres lost 15,000 shops from 2000 to 2009 (Portas, 2011), and the national shop vacancy rate varies between $14 \%$ and $16 \%$. Shopping surface area fell by $14 \%$ within cities, while it increased by $30 \%$ in peripheries (Portas, 2011). According to Mary Portas (2011), less than $43 \%$ of British household purchases are made today in high streets, even though the pace of decline has slowed slightly in recent years. In 2011, one in six shops in town centres was vacant in Great Britain. Vacancy more than doubled between 2008 and 2012, rising from $7 \%$ to $16 \%$ (Wrigley \& Lambiri, 2014).

The decline of retailing in urban centres is especially pronounced in small cities. In every country covered by our literature review, shop vacancy has increased more rapidly in the centres of small and medium-sized towns than in those of large cities. While these dynamics are not peculiar to small and medium-sized cities, they have been all the more affected because their retail vitality was based on a smaller number of shops than found in the big cities. The opening of a shopping centre in small and medium-sized town and cities has had much stronger effects on the decline of the central stores. In addition, the impact of vacant spaces is particularly visible (Robertson, 1999). Their centres are also more vulnerable to competition from peripheral shopping centres (Filion, Hoernig, Bunting, \& Sands, 2004; Filion, 2008). In Great Britain, a report by the Department of the Environment as early as 1998 indicated that the development of supermarkets had had an adverse impact on market towns. Two years earlier, the Planning Policy Guidance Note 6 (PPG6) highlighted the adverse effects of peripheral retail developments, which threatened the viability of the centres of small and mediumsized cities and rural towns, and it imposed a test for the location of periurban retail settlements, "the so-called 'sequential approach' to store site selection" (Hallsworth \& Coca-Stefaniak, 2018). These regulations, however, did not have the desired effects. In the mid-1990s, a study showed that $15 \%$ of British market towns were undergoing decline. Later on, with the "Needs test", the retail developers were required to demonstrate that there was a 'need' for stores (Guy, 2006). However, the effects of the "Town Centres First" policy promoted by the British Government Minister Richard Caborn have been difficult to assess ${ }^{6}$. Over the past two decades, small retail outlets have experienced further decline in market towns ${ }^{7}$ (Wrigley \& Lambiri, 2014; Hallsworth \& Coca-Stefaniak, 2018). Also in the UK, Singleton et al. (2016) have shown that the centres of medium-sized towns located in rural areas or on the outskirts of major cities are very vulnerable to the development of e-commerce. In the United States, experts at the Brookings Institution (Katz \& Frey, 2017) have also noted the decline of centres in small and medium-sized towns. In the North American context, work on the resilience of city centres and their shopping streets (Balsas, 2014) has shown that in medium-sized towns, the creation of secondary centres can significantly weaken vitality of traditional centres. Small and medium-sized towns have thus suffered more from the negative effects of suburbanisation because they do not have the advantages of large cities to resist. In these towns, given the absence of additional demand, the development of retailing is a zero-sum game: any new commercial development is likely to cause a weakening of existing clusters (Balsas, 2014). Similarly, the average vacancy rate of traditional covered shopping streets in Japan (shôtengai), some of which having existed since the $16^{\text {th }}$ century, is $14,6 \%$ nationwide in 2012 , but this rate is as high as $20 \%$ in municipalities with less than 200,000 inhabitants which are not regional capitals. By contrast, the rate rarely exceeds $9 \%$ in the downtown areas of bigger cities (Tsujii, 2013).

\footnotetext{
${ }^{5}$ Between 1980 and 2000, depending on the country.

${ }^{6}$ The tests were suppressed in 2008, at the same time as the subprime crisis started.

${ }^{7}$ As underlined by Portas (2011), "consumers have had less money to spend in general, let alone on the high street".
} 
In the United Kingdom, studies show that the commercial vitality of urban centres is linked to their economic vitality and especially to the presence and availability of many jobs. ${ }^{8}$ The least economically dynamic urban centres are also those with the highest shop vacancy (McDonald \& Swinner, 2019). Similarly, the cities most affected by retail decline are cities facing fragile economic contexts, according to Wrigley and Lambiri (2014). The combination of the size of the urban centre and local economic conditions plays an important role in the retail vitality of a city. In addition, the diversity of shops and services offered in an urban centre has a protective effect on the business performance of a town centre. Conversely, Wrigley and Lambiri (2014) indicate that the strong presence of independent stores does not create conditions that are necessarily conducive to the retail vitality of an urban centre.

\section{Retail decline in small and medium-sized French cities: background elements}

\section{Perspectives on the retail transformation of small and medium size cities in France, 1979-2014}

In France, since the 1970s, there has been a rise in the retail clusters in peripheral areas and a weakening of secondary centralities or city centres. Thus, in 1997, suburbs hosted about $38 \%$ of jobs in retailing and $30 \%$ of retail outlets, figures which rose respectively to about $41 \%$ and $32 \%$ in 2008 . This transfer of activity has been accompanied by a decline in the number of retail outlets and the retail surface area in town centres. Many case studies have born witness to this evolution: Dijon (Chemla, 1992), Aix-en-Provence (Vaudour-Jouve, 1992), Saint-Nazaire (Desse, 1991), Brest (Desse, 1991), Tours (Bachelard, 1991), Chartres (Ainquez-Virinat, 1992), Rouen (Lemarchand, 1992), Bordeaux (Cassou-Mounat, 1992), or even Cerizay, Melle and Saint-Maixent-L'École (Soumagne, 1975). This vulnerability is especially visible in the urban landscape, with the development of shop vacancies in the shopping streets of town centres (Madry, 2017).

At the same time, stores affiliated with a chain have become increasingly important (MérenneSchoumaker, 2003; Delobez \& Péron, 1991). France moreover is considered as one of the first countries in Europe to have experienced the concentration and suburbanisation of retail trade (Fernandes \& Chamusca, 2014). It is also one of the countries with the largest internationalised groups specialised in retailing (Huang \& Sternquist, 2007; Coe, 2004). E-commerce pushes upwards in France too : in 2014, its turnover was nearly $€ 65$ billion, with more than $14 \%$ annual growth since 2005, while its weight in retail trade was nearing $9 \%$ (Rallet, 2001; CGEDD, 2017;).

This shift in the distribution of retail activities within cities and in the retail trade affects small and medium-sized towns more than larger cities. Madry $(2016)^{9}$ finds that the shop vacancies increased significantly in all cities between 2001 and 2015. ${ }^{10}$ In small and medium-sized towns, vacancies rose by respectively $6.3 \%$ and $8.6 \%$ in city centres, and by $5 \%$ and $7 \%$ in their peripheral shopping centres in these years. This compares with $6.3 \%$ and $7.1 \%$ for all cities surveyed. ${ }^{11}$ Shop closures, however, are not something new: between 1920 and 1960, half of all the shops in France closed, and declines continued between 1960 and 1980 (Madry, 2013, 2016). Work by Bessière and Trévien (2016) ${ }^{12}$ shows that retailing and employment have declined particularly in the inner cities of urban areas with less than 500,000 inhabitants. The decline in employment in the retail sector has affected $85 \%$ of average-sized urban areas, compared to $31 \%$ of very large urban areas. At the same time, retailing is

\footnotetext{
8 "The real challenge for retailers is insufficient footfall in their city centres, due to the lack of jobs in these central locations, which would provide customers during the week" (McDonald \& Swinner, 2019).

9 These studies draw on the Base Codata database, a support tool for retail and commercial real estate professionals. Since 2001, it has compared retail outlets of 200 city centres and 450 shopping centres in French urban units with more than 50,000 inhabitants.

${ }^{10}$ In 2015 , 100 city centres and 87 outlying shopping centres had a shop vacancy rate of over $10 \%$, compared with 23 city centres and 62 shopping centres in 2001.

11 The rise in vacancies is particularly noticeable in the city centres of Carcassonne, Châtellerault, Guéret, Nevers, Romans, Vierzon, Alençon, Autun, Forbach, St-Brieuc, and Sarreguemines, where the vacancy rate can reach $30 \%$.

12 Their work relates to 250 urban areas with more than 20,000 inhabitants, excluding the greater Paris urban area.
} 
very dynamic outside the central clusters, whether in terms of growth in the number of retail outlets $(+12 \%)$ or in job growth $(+14 \%)$ (Bessière \& Trevien, 2016).

For all these reasons, our paper wonders how retail decline affects French towns and cities. We seek to quantify retail decline in the subset of small and medium-sized towns and cities which the literature claims to have been especially affected by this decline. The above mentioned review of the French literature has indeed shown that retail decline started in French city centres as early as in the late 1970s. It has been particularly relevant to shoe, clothing, furniture and appliance businesses (Barczark $\&$ Hilal, 2016). We therefore propose to quantify retail decline since the late 1970s, by measuring the decrease in the presence of these four types of businesses in municipalities located in the municipalities ${ }^{13}$ of small and medium-sized towns. To examine the relationship between retail decline and the dynamics of urbanisation, we test six explanatory hypotheses of retail decline for this set of shops:

- Retail decline is a phenomenon that does not weaken over time.

- Retail decline is more frequently observed in central than in peripheral municipalities.

- Retail decline occurs more frequently central municipalities within small urban areas than medium-sized ones.

- Municipalities located in urban areas undergoing population losses (rather than demographic gains) are more vulnerable to retail decline.

- Retail decline is more frequently observed in municipalities located within larger urban areas/agglomerations where there is a supermarket or a hypermarket

- Finally, employment mobility can also exert a strong influence on retail decline. Retail decline is less common in municipalities where a notable share of the jobs is occupied by persons who do not reside in the municipality.

\section{Methods}

Our study focuses on French small and medium-sized towns and cities which are more affected by the phenomena of retail decline. Attempts at outlining them raises many issues and an abundant literature examines relevant criteria for a definition (Edouard 2008, 2012; Santamaria, 2000, Vadelorge, 2013). ${ }^{14}$ Here we define this category as being functional areas whose central urban unit has less than 100,000 inhabitants, ${ }^{15}$ as well as urban units of less than 100,000 inhabitants located outside urban areas. This provides us with 1,235 areas which we refer to as "functional urban areas" (FUAs) below. Our analysis subsequently looks at retail decline in 9,189 municipalities belonging to these 1,235 FUAs. These 1,235 functional urban areas comprise all the small and medium-sized towns and cities in France. Our study covers the years 1979-2014, that we divide into four successive sub-periods, depending on the availability of data. The municipalities include 978 central municipalities of a FUA, 2,171 suburban municipalities, and 625 so-called "isolated city" municipalities, which together make up for $41 \%$ of the sample ${ }^{16}$. The remaining $58 \%$ is composed of 5,415 periurban municipalities ${ }^{17}$.

There was an increase in the number of inhabitants during the 40 years of the study in all municipalities. The median population of municipalities increased from 474 to 707 inhabitants between 1968 and 2013. However, there are large variations in these distributions. In 2013, one

\footnotetext{
${ }^{13}$ France still retains over 36,000 municipalities, called "communes". These are the smallest administrative units of local government, although they can vary greatly in size. In this text, communes has been translated by "municipalities".

14 The authors use a threshold of 100,000 inhabitants, though they do not specify if this size criterion applies to a functional, morphological or municipal demarcation.

${ }^{15}$ Due to a statistical problem in France.

16 These are the municipalities which are located in urban units. The sample we are studying goes beyond this perimeter as we also observe erosion in the periurban municipalities of urban areas.

${ }^{17}$ The characterisations (centre, isolated, suburban, periurban) were established by France's National Institute of Statistics and Economic Studies (INSEE) in 2010, and we assigned them to all dates, even though they may have changed during the period. They are specified in Table 1.3.
} 
quarter of the municipalities had less than 340 inhabitants and another one had more than 1,796 inhabitants (Table 1.1).

Table 1.1: Summary of population statistics in functional urban areas and municipalities

\begin{tabular}{|c|c|c|c|c|c|c|c|c|c|c|}
\hline & \multicolumn{2}{|c|}{$\begin{array}{l}\text { Minimum } \\
\text { population }\end{array}$} & \multicolumn{2}{|c|}{$\begin{array}{l}\text { First quartile of } \\
\text { population }\end{array}$} & \multicolumn{2}{|c|}{$\begin{array}{c}\text { Median } \\
\text { population }\end{array}$} & \multicolumn{2}{|c|}{$\begin{array}{c}\text { Third quartile of } \\
\text { population }\end{array}$} & \multicolumn{2}{|c|}{$\begin{array}{l}\text { Maximum } \\
\text { population }\end{array}$} \\
\hline $\begin{array}{c}\text { Pop } \\
\text { ulati } \\
\text { on }\end{array}$ & $\begin{array}{c}\text { Functiona } \\
\text { l urban } \\
\text { area }\end{array}$ & $\begin{array}{c}\text { muni } \\
\text { cipali } \\
\text { ty }\end{array}$ & $\begin{array}{c}\text { Functiona } \\
\text { l urban } \\
\text { area }\end{array}$ & $\begin{array}{c}\text { muni } \\
\text { cipali } \\
\text { ty }\end{array}$ & $\begin{array}{c}\text { Functiona } \\
\text { l urban } \\
\text { area }\end{array}$ & $\begin{array}{c}\text { muni } \\
\text { cipali } \\
\text { ty }\end{array}$ & $\begin{array}{c}\text { Functiona } \\
\text { l urban } \\
\text { area }\end{array}$ & $\begin{array}{c}\text { muni } \\
\text { cipali } \\
\text { ty }\end{array}$ & $\begin{array}{c}\text { Functiona } \\
\text { l urban } \\
\text { area }\end{array}$ & $\begin{array}{c}\text { muni } \\
\text { cipali } \\
\text { ty }\end{array}$ \\
\hline 1968 & 562 & 20 & 2930 & 244 & 4718 & 474 & 9868 & 1139 & 128047 & $\begin{array}{c}8048 \\
1\end{array}$ \\
\hline 1975 & 682 & 16 & 3017 & 239 & 4906 & 491 & 10262 & 1246 & 135915 & $\begin{array}{c}8402 \\
9\end{array}$ \\
\hline 1982 & 889 & 20 & 3090 & 261 & 4996 & 537 & 10776 & 1394 & 144168 & $\begin{array}{c}7664 \\
7\end{array}$ \\
\hline 1990 & 1163 & 16 & 3096 & 285 & 4974 & 586 & 11061 & 1530 & 148373 & $\begin{array}{c}7560 \\
9\end{array}$ \\
\hline 1999 & 1166 & 14 & 3123 & 296 & 5057 & 610 & 11267 & 1598 & 153862 & $\begin{array}{c}7248 \\
0\end{array}$ \\
\hline 2006 & 1262 & 14 & 3241 & 318 & 5283 & 666 & 11672 & 1705 & 163296 & $\begin{array}{c}7224 \\
5\end{array}$ \\
\hline 2013 & 1233 & 15 & 3337 & 340 & 5398 & 707 & 12215 & 1796 & 172558 & $\begin{array}{c}7481 \\
1\end{array}$ \\
\hline
\end{tabular}

Note: For every date, same municipalities $(n=9189)$ and functional urban areas $(n=1235)$ are considered.

Source: French National Censuses for 1968, 1975, 1982, 1990, 1999, 2006, 2013. 
Figure 1.1: Population Growth in the 1,235 Functional Urban Areas under Study

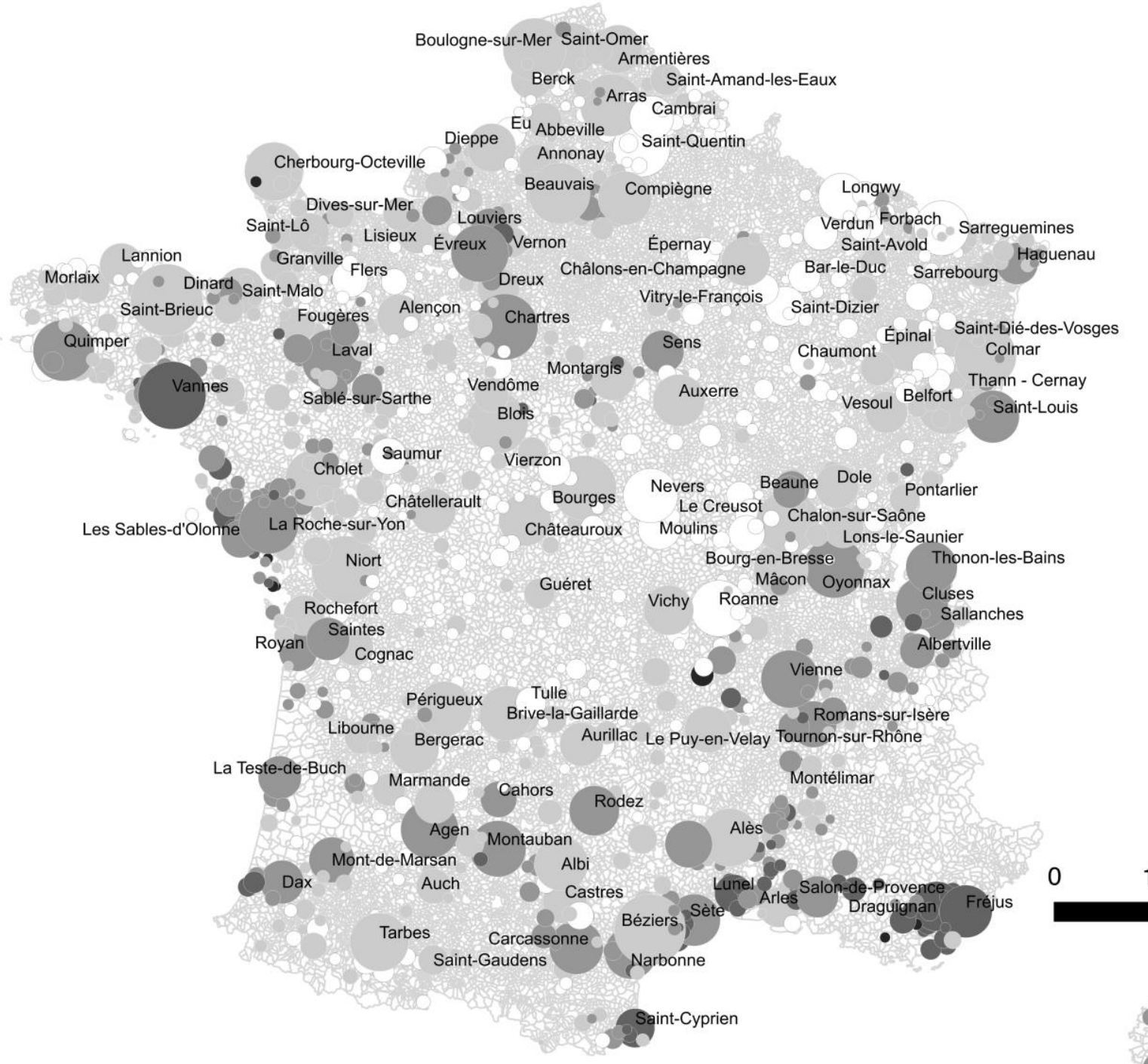

50000

100000

Population in 2013

150000

172558

Relative change in

$-0.4-0 \%$

population between 1975

$\begin{array}{ll}0-0.28 \% \\ & 0.28-0.74 \%\end{array}$

and 2013 (FUAs)

- $\quad 0.74-1.58 \%$

- $1.58-2.85 \%$

Source: INSEE, population censuses.

NB. For ease of understanding, only units with more than 30,000 inhabitants are named.

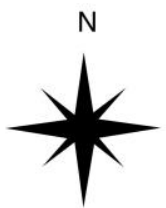




\section{Building an indicator of retail mix decline}

The combination of shop-use frequency and the distance travelled to reach shops make it possible to define a retail mix which groups together four types of shops with intermediate customer use (less than once a month) and/or at medium distance: ${ }^{18}$ clothing, shoe, furniture and household appliance shops. These four types of shops are declining over time. Between 1980 and 2013, the total number of municipalities with these outlets fell for each type: $-5 \%$ for municipalities with a clothing shop; $18.1 \%$ for furniture shops; $-48.3 \%$ for shoe shops; and $-58.7 \%$ for appliance shops. ${ }^{19}$

Four periods are considered: 1979-1988, 1988-1999, 1999-2009, and 2009-2013. They correspond to the census intervals of nationwide surveys on municipal amenities (Table 1.2). A retail diversity index is calculated for each municipality and period, varying from 1 to 4 depending on the type of business present in the municipality. Municipalities that have maintained (or increased) their retail diversity are distinguished from those that have lost diversity over time. The latter are described as having experienced an eroded retail diversity. For example, a municipality which had three types of shops in 1979 (a furniture shop, an appliance shop and a shoe shop) and only one furniture shop in 1998, is identified as having been affected by an erosion of retail diversity.

The construction of this diversity indicator, rather than indicators of business quantity, is due to the fact that the only information available in the French business economic census ${ }^{20}$, over this long period of 1979-2014, concerns physical presence, rather than the total number of businesses. Databases on the number of shops per municipality are not available for the oldest inventories, while databases on retail surface areas (provided by private companies) do not give data on all types of shops (threshold levels exist for the availability of data), and these databases were only generalised from the 1990s onwards. Moreover, databases providing figures for earnings by retail outlets have only been available as of 2017. But retail diversity is at the heart of the dynamics of city centres and shopping centres, because it is a vector of centrality. Diversity is also the support of social representations, linked to the vibrancy of public spaces and shopping streets, with a variety of small shops remaining one of the strong symbols of the small and medium-sized cities, whether in city centres, or in the surrounding boroughs.

Table 1.2: Data Sources

\begin{tabular}{|l|l|l|}
\hline Data & Sources and description & Year \\
\hline Population & $\begin{array}{l}\text { Available from the 1968,1975, 1982, } \\
1990,1999,2006 \text { and 2013 french } \\
\text { census (INSEE) }\end{array}$ & $2006 ; 2013$ \\
\hline municipality category & $\begin{array}{l}\text { Available from the 2010 french } \\
\text { census (INSEE) and subsequent } \\
\text { Zonage en unite urbaine' }\end{array}$ & 2010 \\
\hline Commuting in/outside municipality & $\begin{array}{l}\text { Available from the 1968, 1975, 1982, } \\
1990,1999,2006 \text { and 2013 Census of } \\
\text { France (INSEE) }\end{array}$ & $2006 ; 2013 ; 1990 ; 1999 ;$ \\
\hline Mass-market retailing & $\begin{array}{l}\text { Available from the 1979, 1988, 2009 } \\
\text { and 2014 Inventaire communal and } \\
\text { Base Permanente des Equipements } \\
\text { (BPE), from INSEE, equal to business } \\
\text { economic census }\end{array}$ & \\
\hline
\end{tabular}

\footnotetext{
${ }^{18}$ In France, the median time of travel to these retail establishments is 7 to 17 minutes, and this increases with the isolation of the communes (Barzack \& Hilal, 2016).

19 The data come from Barzack and Hilal, 2016. The fact that there are or are not these specialities is not necessarily a factor of commercial dynamism or decline.

${ }^{20}$ The 'Base permanente des équipements', similar to the business economic census, gives, for each year of census and municipality, the presence of different types of shops.
} 


\section{Explaining retail erosion: A two-scale analysis of four categories of variables}

A two-scale analysis is used (see Table 1.3). The first spatial scale is the municipality, which is the smallest spatial scale available for the long period of study. By contrast, the second scale we used concerns functional urban areas (FUAs). These two spatial scales are used in the analyses and regressions.

This analysis combines four variables:

Population size and growth. The size and dynamics of the market are captured with population variables. Two spatial scales are taken into account: 1) the municipality, which helps to characterise the presence of store catering to local demands and neighbourhood-level consumption practices and 2) the FUA which allows the attraction capacity of the central cluster to be captured.

The position of a municipality in a functional urban area. The location of municipalities (centre, suburbs, periurban, isolated) in an FUA.

Commuting in/outside municipalities. The role of mobility in retail practices is considered with two indicators characterising employment areas. The internal employment rate is computed as the percentage of the labour force living and working in the municipality out of the total labour force living in the municipality, for each census date. We thus put forward the hypothesis that a municipality with a high internal employment rate is less likely to suffer retail decline because residents are potential customers during the day. Secondly, the external employment rate is computed as the percentage of the labour force living and working in the municipality out of the total labour force working in municipality (living inside and outside the municipality). This measures the capacity of a municipality to attract labour force from surrounding areas. It shows whether the local labour market is self-sufficient or whether the municipality brings in workers to occupy jobs not occupied by residents. If the municipality "imports" a significant portion of its workforce, and therefore if the external rate is low, retail trade erosion may be slowed by the population intake during the day, which increases retail demand.

Mass-market retailing. Finally, competition among retailers is measured using an indicator for the presence of a supermarket and/or hypermarket in the municipality.

Table 1.3: The Independent Variables of the Model for Retail Decline

\begin{tabular}{|l|l|}
\hline \multirow{2}{*}{ Population } & Definition and quantification \\
\hline $\begin{array}{c}\text { Municipality } \\
\text { population }\end{array}$ & Population in thousand \\
\hline $\begin{array}{c}\text { Functional urban area } \\
\text { population }\end{array}$ & $\begin{array}{l}\text { Functional urban area (FUA) population is categorized in three groups using population } \\
\text { distribution. }\end{array}$ \\
\cline { 2 - 2 } & Very small urban areas: The 25 per cent less populated FUA's \\
\cline { 2 - 2 } & Small urban areas: The 50 per cent FUA between the first and the third quantile \\
\cline { 2 - 2 } & Medium urban areas: The 25 per cent FUA more populated urban areas \\
\hline $\begin{array}{c}\text { Population growth at } \\
\text { municipality level }\end{array}$ & Average annual population growth of the municipal population between two census dates \\
\hline $\begin{array}{c}\text { Population growth at } \\
\text { FUA level }\end{array}$ & average annual population growth of the FUA population between two census dates \\
\hline
\end{tabular}




\begin{tabular}{|c|c|}
\hline \multicolumn{2}{|l|}{$\begin{array}{l}\text { Municipality location } \\
\text { in the functional } \\
\text { urban area }\end{array}$} \\
\hline & 4 types: Center, suburbs, periurban municipality or belonging to an isolated town. \\
\hline & $\begin{array}{l}\text { According to the French census, the notion of urban unit ('unité urbaine') is based on the } \\
\text { continuity of built up land mass and the number of inhabitants. In France, an urban unit is } \\
\text { a municipality ('commune') or a group of municipalities which includes a continuously built } \\
\text { up zone (no cut of more than } 200 \text { meters between two constructions) and at least } 2,000 \\
\text { inhabitants. If the urban unit is composed by only one municipality, it is called an isolated } \\
\text { town. If the urban unit extends over several municipalities, and if each of these } \\
\text { municipalities concentrates more than half of its population in the continuously built up } \\
\text { zone, it is called a multi-municipal agglomeration, including a centre (the most populated } \\
\text { municipality), and outlying or suburban municipalities (located in the continuous built up } \\
\text { zone). Municipalities are considered rural when they are not included in an urban unit (i.e., } \\
\text { municipalities of } 2000 \text { inhabitants with no continuously built-up zone, and the } \\
\text { municipalities in which less than half of the municipal population is settled in a zone of } \\
\text { built continuously built up zone). In our case study, rural municipalities are by definition } \\
\text { included in an urban area, so we called them periurban municipality. }\end{array}$ \\
\hline \multicolumn{2}{|c|}{\begin{tabular}{l|l} 
Commuting in/outside \\
municipality
\end{tabular}} \\
\hline $\begin{array}{l}\text { internal employment } \\
\text { rate }\end{array}$ & $\begin{array}{l}\text { rate of local workers among resident workforce (it corresponds to the number of residents } \\
\text { working in the municipality over the total number of resident working whether in or outside } \\
\text { the municipality) }\end{array}$ \\
\hline $\begin{array}{l}\text { external employment } \\
\text { rate }\end{array}$ & $\begin{array}{l}\text { rate of resident workers among local workforce (it corresponds to the number of residents } \\
\text { working in the municipality over the total number of people working locally, whether } \\
\text { resident or non-resident) }\end{array}$ \\
\hline \multicolumn{2}{|l|}{$\begin{array}{l}\text { Mass-market retailing } \\
\text { in the municipality }\end{array}$} \\
\hline $\begin{array}{l}\text { supermarket and } \\
\text { hypermarket }\end{array}$ & presence or absence in the municipality \\
\hline
\end{tabular}

Table 1.4: Statistical Summary

\begin{tabular}{|c|c|c|c|c|c|c|c|}
\hline Population size & 1968 & 1975 & 1982 & 1990 & 1999 & 2006 & 2013 \\
\hline Municipality population : mean & 1580 & 1679 & 1740 & 1789 & 1824 & 1893 & 1941 \\
\hline Functional urban area (FUA) population : & 1182 & 1255 & 1302 & 1340 & 1367 & 1419 & 1456 \\
\hline mean & 5 & 8 & 1 & 4 & $t$ & 9 & 2 \\
\hline Population Growth & & $\begin{array}{l}1968- \\
1975\end{array}$ & $\begin{array}{l}1975- \\
1982\end{array}$ & $\begin{array}{l}1982- \\
1990\end{array}$ & $\begin{array}{l}1990- \\
1999\end{array}$ & $\begin{aligned} 1999- \\
2006\end{aligned}$ & $2006-$ \\
\hline $\begin{array}{l}\text { Population growth at municipality level : } \\
\text { mean }\end{array}$ & & 0,04 & 0,1 & 0,1 & 0,04 & 0,72 & 0,06 \\
\hline Population growth at FUA level : mean & & 0,06 & 0,04 & 0,02 & 0,02 & 0,04 & 0,02 \\
\hline Location in the FUA & & & & & & 2010 & \\
\hline Number of center municipalities & & & & & & 978 & \\
\hline Number of suburbs municipalities & & & & & & 2171 & \\
\hline Number of municipalities in an isolated & & & & & & 625 & \\
\hline Number of periurban municipalities & & & & & & 5415 & \\
\hline Commuting in/outside Imunicipality & 1968 & 1975 & 1982 & 1990 & 1999 & 2010 & \\
\hline Internal employment rate : mean & 65 & 54 & 45 & 35 & 27 & 25 & \\
\hline External employment rate : mean & 83 & 75 & 71 & 63 & 53 & 52 & \\
\hline Mass-market retailing in $\mathrm{t}$ & & & 1979 & 1988 & 1998 & 2009 & 2014 \\
\hline $\begin{array}{l}\text { Number of municipalities with at least one } \\
\text { super or hypermarket }\end{array}$ & & & 1116 & 1625 & 1809 & 2031 & 2088 \\
\hline
\end{tabular}




\section{Statistical methods: logistic regressions}

First, we compared municipality rates with retail decline over the four periods (1979-1988, 19881998, 1998-2009, 2009-2014), as shown by table 1.5. Then, according to the variables previously described (related to population size, population growth, position in the functional urban area, commuting in/outside municipality and mass-market retailing), we compared municipality profiles with/without retail decline first using bivariate analysis (Table 1.6), and then using multivariate logistic regression models (Table 1.7).

Four logistic regression models are implemented combining the same set of explanatory variables for the four periods (1979-1988, 1988-1998, 1998-2009, 2009-2014). The binary dependent variable indicates the occurrence of the erosion of retail diversity so that we model the logit of the probability of decline $\left(\mathrm{P}_{\mathrm{d}}\right)$ as a linear function:

$$
\log \left(\frac{P_{d}}{1-P_{d}}\right)=\beta_{0}+\beta_{1} x_{1 i}+\beta_{2} x_{2 i}+\cdots+\beta_{k} x_{k i}
$$

As there is no inferential design in our data, we don't consider any p-value, we just consider the coefficient values or the exponentialized value as odds ratios and the McFadden's squared R for the global model assessment.

\section{Results}

The erosion of the retail mix following peak diversity in the 1990s

In all periods, the erosion of diversity in retailing, which we call here the "retail mix decline" is always a minority phenomenon. The general rule is for the diversity of amenities to be maintained or increased. Nevertheless, the number of municipalities registering retail mix decline did increase between the first two periods (from 33\% to 46\%), then levelled-off (at 44\%) in the third period, before declining during the last period (25\%): Table 1.5. Finally, between a quarter and a little more than half of municipalities have lost one type of retail trade every 10 years, on average.

Table 1.5: The Decline of the Retail Mix

\begin{tabular}{|c|c|c|c|c|}
\hline & $\begin{array}{c}\text { 1rst period. } \\
\mathbf{1 9 7 9 - \mathbf { 1 9 8 8 }}\end{array}$ & $\begin{array}{c}\text { 2nd period. } \\
\mathbf{1 9 8 8}-\mathbf{1 9 9 8}\end{array}$ & $\begin{array}{c}\text { 3rd period. 1998 } \\
\mathbf{- 2 0 0 9}\end{array}$ & $\begin{array}{c}\text { 4th period. 2009 } \\
\text { - 2014 }\end{array}$ \\
\hline $\begin{array}{c}\text { Number of } \\
\text { municipalities } \\
\text { with at least one } \\
\text { of the 4 } \\
\text { commercial } \\
\text { types at the } \\
\text { beginning of the } \\
\text { period }\end{array}$ & 3089 & 2940 & 2486 & 2518 \\
\hline $\begin{array}{c}\text { Number (\%) of } \\
\text { municipalities } \\
\text { with retail mix } \\
\text { decline observed } \\
\text { at the end of the } \\
\text { period. }\end{array}$ & $1012(33 \%)$ & $1342(46 \%)$ & $1101(44 \%)$ & $629(25 \%)$ \\
\hline
\end{tabular}

Municipalities that have experienced an erosion of their retail diversity are distributed in a rather diffuse manner throughout the whole of France. Since 1988, the West, Brittany and the East have been more affected. France's de-industrialised regions and regions of demographic stagnation appear 
to have been most affected, if we take out the more specific dynamics affecting South-West France. Conversely, the municipalities registering retail mix decline are not very present on the coasts of Languedoc-Roussillon and Provence-Alpes-Côte d'Azur, nor in the Rhone valley. A spread in retail mix decline then occurred between 1988 and 2009: all regions and most cities were affected. During the last period, the retail mix decline affected municipalities less and was scattered throughout the territory; this decrease is probably due to the fact that this period was half as long as the others ( 5 years instead of 10).

\section{The Role of Each Explanatory Factor in the Decline of the Retail Mix}

Bivariate analyses (Table 1.6) allow some explanatory factors to be identified. The size of cities is one of these factors. Thus, in the first period, between 1979 and 1988, retail mix decline (-26\%) affected less very small towns (less than 3,000 inhabitants in 1975). Instead, it affected more small towns (between 3,000 and 10,000 inhabitants), as well as average towns/cities (more than 10,000 inhabitants), which accounted for respectively $36 \%$ and $40 \%$ of municipalities experiencing retail mix decline. ${ }^{21}$ During the last period, between 2009 and 2014, these three FUA categories appear to have been affected to more or less to the same extent (between 23\% and 29\%): see Table 1.6. It is therefore likely that the very small towns retained their retail centrality until the beginning of the $1990 \mathrm{~s}^{22}$. But, from the 1990s onwards, retail mix decline affected towns and cities of all sizes.

The second factor concerns population growth which, at municipality-level, made it possible to limit retail mix decline before the beginning of the 2000s, but had no effect thereafter. By contrast, population growth at the FUA level does not stand out as a factor explaining retail mix decline, in any period.

The position of a municipality in the FUA appears to be the third explanatory element: in all periods, the strongest retail mix decline is recorded in periurban municipalities, and in suburban municipalities.

Finally, the mobility of populations plays a significant role. Whatever the period, the municipalities experiencing retail mix decline have an internal employment rate which is not as high as in municipalities not facing retail mix decline. When the internal employment rate is low, the proportion of workers leaving the municipality to work is higher, and they are probably more exposed to shops outside the municipality when they commute, thus reducing the level of demand in their municipality of residence, and so aggravating retail decline. Whatever the period in question, we also observe that municipalities with retail mix decline have an external employment rate that is higher than the rate in municipalities without retail mix decline. When the external employment rate is high, local retail outlets cannot count on the external contribution of clients who come into the municipality as the workforce in the municipality is largely made up of local residents.

Table 1.6: Bivariate Analyses of Superior Retail Mix

\footnotetext{
${ }^{21}$ It should be specified that we refer here to municipalities which had at least some retail mix at the outset, and which subsequently suffered from diversity erosion between 1979 and 1988.

${ }^{22}$ The presence of the four selected shops does not necessarily mean that the FUA is dynamic. A municipality almost without shops in the town centre but with one or two medium-sized specialist shops on the municipality outskirts is certainly more dynamic than another without these shops.
} 
Delage M, Baudet-Michel S, Fol S, Buhnik S, Commenges H, Vallée J. Retail decline in France's small and medium-sized cities over four decades. Evidences from a multi-level analysis. Cities, Elsevier, 2020, 104, pp.102790. $\langle 10.1016 /$ j.cities.2020.102790 $\rangle$.

\begin{tabular}{|c|c|c|c|c|c|c|c|c|c|c|c|c|}
\hline \multirow[t]{2}{*}{ - } & \multicolumn{3}{|c|}{$\underline{\text { 1rst period. } 1979-1988}$} & \multicolumn{3}{|c|}{ 2nd period. 1988 - 1998} & \multicolumn{3}{|c|}{ 3rd period. $1998-2009$} & \multicolumn{3}{|c|}{ 4th period. $2009-2014$} \\
\hline & & $\begin{array}{c}\text { Municipalitie } \\
\text { s without } \\
\text { erosion } \\
(\mathrm{n}=2077)\end{array}$ & $\begin{array}{c}\text { Municipalitie } \\
\text { s with } \\
\text { erosion } \\
(\mathrm{n}=1012)\end{array}$ & & $\begin{array}{l}\text { Municipalitie } \\
\text { s without } \\
\text { erosion } \\
(\mathrm{n}=1598)\end{array}$ & $\begin{array}{c}\text { Municipalitie } \\
\text { s with } \\
\text { erosion } \\
(\mathrm{n}=1342)\end{array}$ & & $\begin{array}{c}\text { Municipalitie } \\
\text { s without } \\
\text { erosion } \\
(\mathrm{n}=1385)\end{array}$ & $\begin{array}{c}\text { Municipalitie } \\
\text { s with } \\
\text { erosion } \\
(\mathrm{n}=1101)\end{array}$ & & $\begin{array}{l}\text { Municipalitie } \\
\text { s without } \\
\text { erosion } \\
(\mathrm{n}=1889)\end{array}$ & $\begin{array}{c}\text { Municipalitie } \\
\text { s with } \\
\text { erosion } \\
(\mathrm{n}=629)\end{array}$ \\
\hline \multicolumn{13}{|l|}{ Population size } \\
\hline $\begin{array}{l}\text { Municipality population (in thousand) : } \\
\text { mean }\end{array}$ & 1982 & 54 & 18 & 1990 & 64 & 21 & 1999 & 70 & 26 & 2006 & 59 & 27 \\
\hline Functional urban area population & 1982 & & & 1990 & & & 1999 & & & 2006 & & \\
\hline Very small size: \% & & $74 \%$ & $26 \%$ & & $\mathbf{5 9 \%}$ & $41 \%$ & & $53 \%$ & $47 \%$ & & $77 \%$ & $23 \%$ \\
\hline Small size: \% & & $64 \%$ & $36 \%$ & & $55 \%$ & $45 \%$ & & $61 \%$ & $39 \%$ & & $75 \%$ & $25 \%$ \\
\hline Medium size: \% & & $60 \%$ & $40 \%$ & & $44 \%$ & $56 \%$ & & $52 \%$ & $48 \%$ & & $71 \%$ & $29 \%$ \\
\hline \multicolumn{13}{|l|}{ Population growth } \\
\hline $\begin{array}{l}\text { Population growth at municipality level : } \\
\text { mean }\end{array}$ & $\begin{array}{l}1982 / 197 \\
5\end{array}$ & 0,067 & 0,094 & $\begin{array}{l}1990 / 198 \\
2\end{array}$ & 0,038 & 0,059 & $\begin{array}{l}1999 / 199 \\
0\end{array}$ & 0,031 & 0,028 & $\begin{array}{l}2006 / 199 \\
9\end{array}$ & 0,045 & 0,06 \\
\hline Population growth at FUA level : mean & $\begin{array}{l}1982 / 197 \\
5\end{array}$ & 0,039 & 0,046 & $\begin{array}{l}1990 / 198 \\
2\end{array}$ & 0,029 & 0,026 & $\begin{array}{l}1999 / 199 \\
0\end{array}$ & 0,025 & 0,017 & $\begin{array}{l}2006 / 199 \\
9\end{array}$ & 0,039 & 0,04 \\
\hline Location in the functional urban area & 2013 & & & 2013 & & & 2013 & & & 2013 & & \\
\hline \multicolumn{13}{|l|}{ Municipality types } \\
\hline Center : \% & & $84 \%$ & $16 \%$ & & $72 \%$ & $28 \%$ & & $67 \%$ & $33 \%$ & & $84 \%$ & $16 \%$ \\
\hline Suburbs: \% & & $62 \%$ & $38 \%$ & & $\mathbf{5 0 \%}$ & $50 \%$ & & $56 \%$ & $44 \%$ & & $71 \%$ & $29 \%$ \\
\hline Isolated town: \% & & $75 \%$ & $25 \%$ & & $62 \%$ & $38 \%$ & & $54 \%$ & $46 \%$ & & $76 \%$ & $24 \%$ \\
\hline Periurban : \% & & $46 \%$ & $\mathbf{5 4 \%}$ & & $29 \%$ & $71 \%$ & & $32 \%$ & $68 \%$ & & $61 \%$ & $39 \%$ \\
\hline \multicolumn{13}{|l|}{ Commuting in/outside municipality } \\
\hline Internal employment rate: mean & 1982 & 57 & 47 & 1990 & 52 & 39 & 1999 & 46 & 37 & 2010 & 39 & 30 \\
\hline External employment rate : mean & 1982 & 61 & 65 & 1990 & 51 & 55 & 1999 & 42 & 45 & 2010 & 38 & 40 \\
\hline \multicolumn{13}{|l|}{ Mass-market retailing in the municipality } \\
\hline Super or Hypermarket & & & & & & & & & & & & \\
\hline Absence: $\%$ & 1979 & $57 \%$ & $43 \%$ & 1988 & 0,36 & 0,64 & 1998 & 0,39 & 0,61 & 2009 & 0,64 & 0,36 \\
\hline Presence:\% & & $86 \%$ & $14 \%$ & & 0,72 & 0,28 & & 0,65 & 0,35 & & 0,8 & 0,2 \\
\hline
\end{tabular}




\section{Logistic Regression Models: Significant Explanatory Power}

The proportion of variance explained by the models shown in Table 1.7 is in a range of $27 \%-13 \%$ (in terms of McFadden's squared R). For the first period, the following combination of features led to retail mix decline: small towns situated in suburbs, in periurban or isolated areas, with low population growth (in contrast to FUAs experiencing net population growth), and which retain few resident employees, as little attractive to employment, and have no hypermarket. This combination is quite predictable, except for the population growth of the FUA which was thought to favour the maintenance of diversity, regardless of the size of the municipalities. The combination of features which has resisted retail mix decline is the opposite: a central municipality, which is populated and has high population growth, with a hypermarket, a high internal employment rate (residents of the municipality work locally), a low external employment rate (the municipality attracts outsiders into local jobs), and it is located in an FUA with low population growth.

The combination of features leading to retail mix decline in the second period is almost the same: a sparsely populated municipality, with low growth, facing external competition for jobs and which is unattractive to outside workers. In this case, the combination limiting retail decline is therefore the opposite: a populated municipality, with high population growth, a high internal employment rate (the workers remaining in the municipality), and a low external employment rate (many workers coming to the municipality to work), and a hypermarket.

In the third period, the combination that favoured retail mix decline persisted, except that the explanatory power of the municipality's situation reappeared, being more detrimental to city centres: other things being equal, the suburban municipalities were less likely to record erosion than city/town centres. The explanatory power of the model declined slightly to $23.5 \%$.

In the last period (2009-2014), the probability of registering a retail mix decline was greater for the sparsely populated municipalities, isolated rural boroughs, with a high external employment rate (thus attracting few outside workers relative to local, resident workers). Here the fragility of urban municipalities re-emerges as they are secondary clusters located on the peripheral fringes of FUAs.

Table 1.7: Logistic regression models 
Delage M, Baudet-Michel S, Fol S, Buhnik S, Commenges H, Vallée J. Retail decline in France's small and medium-sized cities over four decades. Evidences from a multi-level analysis. Cities, Elsevier, 2020, 104, pp.102790. 〈10.1016/j.cities.2020.102790〉.

\begin{tabular}{|c|c|c|c|c|c|c|c|c|}
\hline \multirow[t]{2}{*}{-} & \multicolumn{2}{|c|}{$\underline{\text { 1rst period. } 1979-1988}$} & \multicolumn{2}{|c|}{ 2nd period. 1988 - 1998} & \multicolumn{2}{|c|}{ 3rd period. $1998-2009$} & \multicolumn{2}{|c|}{ 4th period. $2009-2014$} \\
\hline & & Coeff. & & Coeff. & & Coeff. & & Coeff. \\
\hline \multicolumn{9}{|l|}{ Population size } \\
\hline Municipality population (in thousand) & 1982 & $-0,018$ & 1990 & $-0,02$ & 1999 & $-0,019$ & 2006 & $-0,011$ \\
\hline Functional urban area population & 1982 & & 1990 & & 1999 & & 2006 & \\
\hline Very small size & & Ref. & & Ref. & & Ref. & & Ref. \\
\hline Small size & & 0,092 & & $-0,015$ & & $-0,17$ & & 0,132 \\
\hline Medium size & & $\mathbf{0 , 0 7 1}$ & & 0,236 & & 0,021 & & 0,109 \\
\hline \multicolumn{9}{|l|}{ Population growth } \\
\hline Population growth at municipality level & $1982 / 1975$ & $-0,696$ & $1990 / 1982$ & $-0,813$ & $1999 / 1990$ & $-1,555$ & $2006 / 1999$ & $-0,23$ \\
\hline Population growth at FUA level & $1982 / 1975$ & $\mathbf{1 , 5 5}$ & $1990 / 1982$ & $-0,698$ & $1999 / 1990$ & $-1,634$ & $2006 / 1999$ & $-0,377$ \\
\hline \multicolumn{9}{|l|}{ Location in the functional urban area } \\
\hline \multicolumn{9}{|l|}{ Municipality types } \\
\hline Center & & Ref. & & Ref. & & Ref. & & Ref. \\
\hline Suburbs & & $\mathbf{0 , 3 0}$ & & $-0,11$ & & $-0,43$ & & 0,00 \\
\hline Isolated town & & $\mathbf{0 , 3 3}$ & & 0,18 & & 0,13 & & $\mathbf{0 , 2 9}$ \\
\hline Periurban & & $\mathbf{0 , 5 8}$ & & 0,14 & & $-0,07$ & & $-0,03$ \\
\hline \multicolumn{9}{|l|}{ Commuting in/outside municipality } \\
\hline Internal employment rate & 1982 & $-0,015$ & 1990 & $-0,019$ & 1999 & $-0,019$ & 2010 & $-0,018$ \\
\hline External employment rate & 1982 & $\mathbf{0 , 0 0 8}$ & 1990 & 0,012 & 1999 & 0,019 & 2010 & $\mathbf{0 , 0 1 1}$ \\
\hline \multicolumn{9}{|l|}{ Mass-market retailing in the municipality } \\
\hline \multicolumn{9}{|l|}{ Super or Hypermarket } \\
\hline Absence & 1979 & Ref. & 1988 & Ref. & 1998 & Ref. & 2009 & Ref. \\
\hline Presence & & $-0,389$ & & $-0,476$ & & $-0,245$ & & $-0,138$ \\
\hline Global model assessment : McFadden's squared R & & 0,216 & & 0,274 & & 0,235 & & 0,114 \\
\hline
\end{tabular}




\section{Discussion}

The explanatory power of the models remained above $20 \%$ until 2006 (Table 1.7), and then decreased to $11 \%$. At first glance, these levels of explanation may seem weak. However, it should be recalled that the logistic models were established not to predict the retail decline, but to test the same combination of four families of measurable explanatory factors through time (40 years). These models thus leave out explanatory variables that are difficult to measure, such as entrepreneurial strategies, the role of actors and public policies. For the last period (2009-2014), the explanatory power of the model is particularly weak, but this period is only half as long. Yet, according to the CGEDD $(2016,2017)$, this last period was marked by the increased importance of unmeasured factors, such as tourism flows into municipalities, the unemployment rate, tax burdens, or even the level of rents. In addition, for this period, it could be that the competition between players in the retail sector had become so strong that it blurred the factors explaining the expansion or erosion of retail trade (Madry, 2016).

\section{Some variables retain their explanatory power throughout the period}

First, other things being equal, the size of a municipality is always linked statistically to retail decline (Robertson, 1999; Barczak \& Hilal, 2016; Hallsworth \& Coca-Stefaniak, 2018): the more a municipality is populated, the lower the probability of retail decline.

Secondly, other things being equal, the higher the percentage of inhabitants working in their municipality of residence, the lower the probability of retail decline. These two variables confirm the role of the hierarchy of local residential and employment systems in maintaining retail activities, favouring markets with a large population and operating on the basis of short-term considerations (Wrigley \&Lambiri, 2014).

Third, population growth, combined with other variables, has an explanatory power concerning retail decline at the municipal level (Wrigley \& Lambiri, 2014). Thus, other things being, positive demographic change in a municipality helped limit retail decline between 1979 and 2009. Our hypothesis was therefore confirmed for the first decades. However, from the 2000s onwards, population growth at the municipal level was no longer an explanatory variable for retail decline: in the model, it was no longer associated with the indicator of eroding retail diversity. At the FUA level, the role of population change generally contributed little to explaining erosion: the variable was not statistically associated with the erosion of retail diversity (with the exception of the years 1979-1988). Our hypothesis is therefore partially disapproved: the demographic change of an FUA neither favours nor limits the maintenance of retail diversity. The size category of the FUA in which the municipality is located does not play a role. Contrary to what the literature suggests, the role of FUA size was ultimately not really significant enough to explain the local dynamics of retail diversity.

Fourth, we find that mobility dynamics play a role. When the internal employment rate was high, the probability of erosion was lower in all periods. This result confirms our initial hypothesis that municipalities which retain more of their workers are more likely to maintain their retail diversity. The other mobility variable was the external employment rate, linked to the arrival of non-resident workers: municipalities which are employment clusters attracting non-resident workers have, other things being equal, better chances of keeping the shops making up their retail mix. These results confirm our initial hypothesis. In all periods, specific configurations relating to population mobility stand out as factors limiting the erosion of retailing: retail activities were maintained in small towns and medium-sized towns which do not face direct competition and which captured the bulk of local employment (Wrigley \& Lambiri, 2014). Another factor that seems to limit the erosion of superior retail mix occurs when employment clusters are very attractive for surrounding populations, thus confirming the mutation of retail activities to meet the demands of non-resident populations in a given territory: this is a kind of imported clientele (Madry, 2016). 


\section{Variables with unexpected explanatory behaviour}

The inversion observed in the model concerning the location variable of the municipality is interesting. In fact, while retail mix decline was favourable to suburban, periurban and remote municipalities during the period 1979-1988, in the 1990s this variable was not explanatory, while in 2000s its impact reversed, as retail mix decline affected more city centre than periurban and suburban municipalities. For the period 1979-1988, our results confirm the work of Delobez and Péron (1991) which showed that city centres lost their retail monopoly in the 1980s, but maintained their supremacy over suburban and outlying areas. This situation did not persist into the following periods: from the beginning of the 2000s, the retail decline of city centres reported by Razemon (2016), Grimmeau and Wayens (2016) for Belgium, by Portas (2011) in England, or by various authors (Arata, 2012; Tsujii 2013; Yakushiji \& Takahashi, 2013) and national surveys from the Ministry of Economy, Trade and Industry (METI) in Japan, is confirmed here.

\section{Conclusion}

Retail decline in small and medium-sized cities is a reality; and it is not negligible. In France, a hundred municipalities per year lose one type of retail trade, and this phenomenon has occurred since the 1970s. Separate periods can be identified, and the decrease in diversity was more marked before the 2000s, followed by a slowing since then. Finally, our results partly confirm the findings of empirical studies mentioned in the literature review.

Explaining this decline of retail activity is nevertheless an ambitious undertaking: the factors mobilised in this article (population size, population growth, position in the urban area, commuting in/outside a municipality and mass-market retailing) explain some of the erosion, but not all. Our study therefore invites us to take into account other factors to grasp the dynamics of erosion, and so be able to respond to the reality of local situations. These factors include: the actors in retailing (independent retailers versus franchises, small shops versus supermarkets), public actors, as well as consumer behaviour. For example, the increase in market share through e-commerce in these FUA's is also a response to this decline. The rise of logistics operators, particularly in the e-commerce sector, is also an element that risks influencing the trends shown here. It is therefore necessary to take into account the margins of manoeuvre actors have in pursuing their strategies, whether public or private, and which have probably played a key role in the recent periods. These margins are, however, limited. In most countries, the lack of controls on residential urban sprawl and the permissiveness in allocating permits to build large retail outlets partly explain retail decline in urban centres. The settlement of retail outlets has been little or poorly regulated in Japan (Czinkota \& Kotabe, 2000; Kidokoro, 2008; Sugita, 2008; Iwama, 2017) ), France (CGEDD, 2017) and in the United States (Rao \& Summers, 2016). In general, the loosening of regulations in the allocation of building permits has been a characteristic of situations where large retail chains have promised to create jobs, which is particularly popular with local actors in cities facing demographic or economic decline (Hallsworth \&CocaStefaniak, 2018; CGEDD, 2017). By contrast, in Germany, the regulations on the establishment of large retail premises have remained very restrictive and protective of small shops in city centres. Legislation gives priority to the maintenance of centralities and the guarantee of a "level of public and private services corresponding to the size of cities and their inclusion in the regional hierarchy" (IGF-CGEDD, 2016). Germany also imposes business rules on opening hours and on price flexibility, in addition to strict limitations on the construction of supermarkets (Huang \& Sternquist, 2007). More recently, a bank involved in financing local governments (Banque des Territoires), as well as a central government unit (Commissariat Général à l'Égalité des Territoires) have implemented a "city-heart" (Coeur de ville) policy through a call for tender, inspired by High Street policies in England. Researchers looking at the question have shown that "despite its leveraged effects for revitalising retail trade, housing and public spaces, the plan remains handicapped by inertia in its ways of thinking and implementing territorial public policies" (Delpirou, 2019). 
Moreover, while we have been able to construct original indicators to document retail decline for nearly forty years, we have not been able to quantify precisely these changes, particularly in terms of the number of businesses. Starting in 2008, the BPE has documented annually the number of shops present in each municipality: constructing new indicators of changes in the quantity and diversity of shops for this more recent period would make it possible to observe changes in greater detail, and examine the concentration processes at work during the last decade.

Shop and business diversity is at the heart of the dynamics of city centres and shopping centres, because it is a vector of centrality. It is also a support of urban representations, the squares and shopping streets with varied small shops remaining one of the strong symbols of the small and medium-sized towns, be it in town centres, or in surrounding boroughs. Letting diversity diminish is to challenge one of the strengths of the urban landscape.

\section{Acknowledgments}

This study was supported by the Labex DynamiTe, the Banque des Territoires, and the "Commissariat Général à l'Egalité des Territoires".

\section{Bibliography}

Anquez-Vinat, M.C. (1992). De l'épicerie-buvette à la galerie marchande ou les mutations commerciales dans l'espace central chartrain de 1957 à 1990. In N. Vaudour-Jouve, \& A. Metton (Eds), L'évolution commerciale des villes françaises : 1975-1990 (pp. 251-273). Aix-en-Provence : Université d'Aix-en-Provence.

Arata, M. 新雅史 (2012). 商店街はなぜ滅びるのか Shōtengai ha naze horobiru no ka [Why do our shopping streets disappear ?]. Tōkyō : Kōbunsha shinsho.

Assmann, S. (2018). Consumption of Fast Fashion in Japan. Local Brands and Global Environment, In K. J. Cwiertka \& E. Machotka (Eds), Consuming Life in Post-Bubble Japan: A Transdisciplinary Perspective, Amsterdam, Amsterdam University Press, 49-68.

Bachelard, M. (1991). Les mutations commerciales dans le centre de Tours (1982-1991), In N. Vaudour-Jouve, \& A. Metton (Eds), L'évolution commerciale des villes françaises : 1975-1990 (pp. 80-88). Aix-en-Provence : Université d'Aix-en-Provence.

Balsas C. (2014). Downtown resilience: A review of recent (re)developments in Tempe, Arizona, Cities, 36, 158-169.

Barczak, A., \& Hilal, M. (2016). L'accès aux commerces et services dans les territoires de vie du quotidien, In S. Blancard, C. Détang-Dessendre, \& N. Renahy (Eds), Campagnes contemporaines. Enjeux économiques et sociaux des espaces ruraux français (pp. 97-116). Paris : Editions Quæ.

Bessière, S., \& Trévien, C. (2016). Le commerce de centre-ville : une vitalité souvent limitée aux grandes villes et aux zones touristiques, Insee Première, Paris : INSEE.

Boisnier, C. (2011). Portrait d'entreprise. Les sociétés immobilières d'investissement cotées (SIIC) ou French REITs : foncières des régions et Unibail Rodamco, Flux, 85-86, 89-104.

Buhnik, S. (2018). Comprendre et comparer la dévitalisation des commerces et services dans les villes moyennes. Une revue de la littérature internationale. Rapport pour la Caisse des Dépôts et Consignations, et pour le Commissariat Général à l'Egalité des Territoires. Paris : Université Paris 1 Panthéon-Sorbonne.

Cassou-Mounat, M. (1992). L'évolution récente du centre-ville de Bordeaux, In N. Vaudour-Jouve, \& A. Metton (Eds), L'évolution commerciale des villes françaises : 1975-1990 (pp. 141-152). Aixen-Provence : Université d'Aix-en-Provence.

CGEDD (2017). Inscrire les dynamiques du commerce dans la ville durable, Paris : CGEDD. 
Chemla, G. (1992), 15 ans d'aménagement piétonnier à Dijon, In N. Vaudour-Jouve, \& A. Metton (Eds), L'évolution commerciale des villes françaises : 1975-1990 (pp. 183-207). Aix-en-Provence : Université d'Aix-en-Provence.

Coca-Stefaniak, J.-A., Parker, C., Quin, S., Rinaldi, R., \& Byrom, J. (2009). Town centre management models: a European perspective, Cities, 26, 2, 74-80.

Coe, N.M. (2004). The internationalisation / globalization of retailing: towards an economicgeographical research agenda, Environment and Planning A, 36, 1571-1594.

Czinkota, M. R. \& Kotabe, M. (2000), Japanese Distribution Strategy: Changes and Innovations, London, Thomson Learning Business Press.

Delobez, A., \& Péron, R. (1991). Les zones d'activités commerciales périphériques et le commerce de centre- ville, In G., Pallier., \& et A., Metton (Eds), Le commerce des centres villes (pp. 264-282). Limoges : Presses de l'Université de Limoges et du Limousin.

Delpirou, A., 2019. Action cœur de ville : une réponse en trompe-l'œil à la crise des villes moyennes ?, Métropolitiques, 28 octobre 2019. URL : https://www.metropolitiques.eu/Action-coeur-de-Villeune-reponse-en-trompe-l-oeil-a-la-crise-des-villes.html

Desse, R.P. (1991). Les mutations commerciales dans l'espace central brestois (1982-1990), In G. Pallier., \& et A. Metton (Eds), Le commerce des centres villes (pp. 222-238). Limoges : Presses de l’Université de Limoges et du Limousin.

Desse, R.P. (1992). Commerce et aménagement urbain à Saint-Nazaire ou une ville à la recherche de son centre, In N. Vaudour-Jouve, \& A. Metton (Eds), L'évolution commerciale des villes françaises : 1975-1990 (pp. 125-140). Aix-en-Provence : Université d'Aix-en-Provence.

Donofrio, J.M. (2008). Downtown revitalization: consumers' and city planners' perceived barriers to integrating large-scale retail into the Downtown (Master thesis). San Luis Obispo : University of California Polytechnic State University.

Édouard, J.C. (2008). La petite ville: contexte scientifique et enjeux de développementaménagement, Bulletin de l'Association de Géographes Français, 1, 3-12.

Édouard, J.C. (2012). La place de la petite ville dans la recherche géographique en France. De la simple monographie au territoire témoin, Annales de géographie, 683, 25-42.

Fernandes, J.R., \& Chamusca, P. (2014). Urban policies, planning and retail resilience, Cities, 36, 170-177.

Filion, P., Hoernig, H., Bunting, T., \& Sands, G. (2004). The successful few: Healthy downtowns of small metropolitan regions, Journal of the American Planning Association, 70, 328-343.

Filion, P., \& Hammond, K. (2008). When Planning Fails: Downtown Malls in Mid-Size Cities, Canadian Journal of Urban Research, 17, 2, 1-27.

Grimmeau, J-P., \& Wayens, B. (2016). Les causes de la disparition des petits commerces (19452015), Courrier hebdomadaire du CRISP, 16, 5-14.

Guimaraes, P.P.C. (2016). From liberal to restrictiveness: an overview of 25 years of retail planning in England, Theoretical and Empirical Researches in Urban Management, 11,2, 24-38.

Guimaraes, P.P.C. (2019). Shopping centres in decline: analysis of demalling in Lisbon, Cities, 87, 21-29.

Guy, C., (2006), "Retail productivity and land use planning. Negotiating 'joined-up' retail planning policy", Environment and Planning C, Government \& Policy, 24, 755-770.

Hallsworth, A., \& Coca-Stefaniak, J.-A. (2018). National high street retail and town centre policy at cross roads in England and Wales, Cities, 79, 134-140.

Huang, Y., \& Sternquist, B. (2007). Retailers' foreign market entry decisions: An institutional perspective, International Business Review, 16, 613-629. 
IGF-CGEDD (2016), Revitalisation des centres-villes, Paris : IGF-CGEDD.

Katz, B., \& Frey, P. (2017). The reality of main street, The Brookings Institution, 3 p.

Kickert., C., \& Vom Hofe, R. (2018). Critical mass matters: the long-term benefit of retail agglomeration for establishment survival in downtown Detroit and The Hague, Urban Studies, 55, 5, 1033-1055.

Kidokoro, T. (2008). Urban Regeneration and the Shift of Planning Approaches : The Case of Japanese Regional Cities, In T. Kidokoro, N. Harata, L.P. Subanu, J. Jessen, A. Motte, \& E.P. Seltzer, (Eds.) Sustainable City Regions : Space, Place and Governance, Tokyo, Springer, p. 147-162.

Kikuchi, Y. 菊池慶之 (2018). Chihō toshi no chūshin shigaichi ni okeru fudōsan shōken-ka no kanōsei 地方都市の中心市街地における不動産証券化の可能性 (Perspective of real estate securitization in local cities), 2018年度日本地理学会春季学術大会 (Geographical Society of Japan, Spring 2018 Academic Conference). URL: https://www.jstage.jst.go.jp/article/ajg/2018s/0/2018s_000076/_article/-char/ja/

Kudo, K., Kimura, A., Nozaki, H., \& Ueda, K. (2012). Suggestion for Continuous Cooperation Derived from Cases of Services Supporting People with Limited Access to Shopping Facilities, NRI Papers, $\mathrm{n}^{\circ} 170$.

Lee, R. J., Sener I.P., Mokhtarian P. L., \& Handy., S. L. (2017). Relationships between the online and in-store shopping frequency of Davis, California residents, Transportation Research Part A, 100, $40-52$.

Lemarchand., N. (1992). Création de commerces dans l'agglomération rouennaise en 1975, 1982, $1990 »$, In N. Vaudour-Jouve, \& A. Metton (Eds), L'évolution commerciale des villes françaises : 1975-1990 (pp. 89-108). Aix-en-Provence : Université d'Aix-en-Provence.

Madry, P. (2013). Vacance commerciale, cote d'alerte, Études foncières, 164, 12-17.

Madry, P. (2016), La vacance commerciale, marqueur spatial d'une crise de régime de croissance du commerce moderne, In R-P., Desse, \& S., Lestrade, (Eds), Mutations commerciales et devenir de l'espace marchand (pp. 167-178). Rennes : Presses Universitaires de Rennes.

Madry, P. (2017). La vacance commerciale dans les centres-villes en France, Les Cahiers de l'Institut pour la ville et le commerce, 1, 1-58.

McDonald, R., \& Swinney, P. (2019). City centres: past, present and future. The evolving role in the national economy, Centre for Cities.

MacGregor, N. (2011). Geographic scope, scale and local social structure: Survival of chain and independent retailers in California, 1990-2004 (PhD Thesis). Berkeley : University of California.

Martinez-Fernandez C., Weyman T., Fol S., Audirac I., Cunningham-Sabot E., Wiechmann T., Yahagi H. (2016). Shrinking Cities in Australia, Japan, Europe and the USA : From a global process to local policy responses, Progress in Planning, 105, 1-48.

Mérenne-Schoumaker, B. (2003). Géographie des services et des commerces. Rennes: PUR.

Portas, M. (2011). The Portas Review: An Independent Review into the Future of Our High Streets. London.

Nishihara, J. (2015). Spatial Government System of Newly Merged Municipalities and Population Changes within Municipalities Impacted by those Government Systems: Under a National Promerger Policy of Municipalities in Post-Growth Societies. In M. Hino \& J. Tsutsumi (Eds), Urban Geography of Post-Growth Society, Sendai, Tohoku University Press, 207-223.

Rallet, A. (2001). Commerce électronique et localisation urbaine des activités commerciale. Revue économique, 52, 267-288.

Rao, F., \& Summers, R. J. (2016). Planning for retail resilience: Comparing Edmonton and Portland. Cities, 58, 97-106. 
Razemon, O. (2016), Comment la France a tué ses villes. Paris : Rue de l'Echiquier.

Robertson, K. (1999). Can Small-City Downtowns Remain Viable?. Journal of the American Planning Association, 65, 3, s270-283.

Santamaria, F. (2000). La notion de "ville moyenne" en France, en Espagne et au Royaume-Uni. Annales de géographie, 109, 613, 227-239.

Santamaria, F. (2012). Les villes moyennes françaises et leur rôle en matière d'aménagement du territoire : vers de nouvelles perspectives?. Norois, 223, 2, 13-30.

Singleton, A. D., Dolega, L., Riddlesden, D., \& Longley, P.A. (2016). Measuring the spatial vulnerability of retail centres to online consumption through a framework of e-resilience, Geoforum, 69, 5-18.

Soumagne, J. (1975). Les activités commerciales de trois petites villes poitevines : Cerizay, Melle, St-Maixent-l'École, Norois, 87, 401-423.

Soumagne, J. (1992). Les mutations commerciales à La Rochelle. In N. Vaudour-Jouve, \& A. Metton (Eds), L'évolution commerciale des villes françaises : 1975-1990 (pp. 32-47). Aix-en-Provence : Université d'Aix-en-Provence.

Soumagne, J.(1991). Les spécificités du commerce central dans les petites villes (Exemples dans le Centre-Ouest français). In G. Pallier., \& et A. Metton (Eds), Le commerce des centres villes (pp. 6274). Limoges : Presses de l’Université de Limoges et du Limousin.

Sugita, S. 杉田 聡 (2008). Kaimono nanmin. Mō hitotsu no kōreisha mondai 買物難民 もうひとつ の高齢者問題 [far way from shopping, another problem for the elderly people]. Tokyo : Ootsuki shoten.

Tanaka, D. 田中大介 (2015). Gendai Nihon no konbini to kojinka shakai. Jôhôka jidai ni okeru “nettowâku no shôhi 現代日本のコンビニと個人化社会 — 情報化時代における「ネットワ ークの消費」— (Individualised Society and Convenience Store in Japan. Consumption of Network in the Information Age). 日本女子大学紀要 人間社会学部 第26 号 (Japan Women's University Journal vol.26), 25-39.

Tsujii, K. 辻井啓作 (2013). なぜ繁栄している商店街は1\%しかないのか [Why there are just one percent of shopping streets who are prospering?]. Tokyo : CCC Media House.

Turok I., Mykhnenko V. (2007). The Trajectories of European Cities, 1960-2005, Cities, 24, 3, 165182.

Vadelorge, L. (2013). Les villes moyennes ont une histoire. L'information géographique, 77, 3, 2944.

Vaudour-Jouve, N. (1992). L'organisation de l'espace commercial aixois. In N. Vaudour-Jouve, \& A. Metton (Eds), L'évolution commerciale des villes françaises : 1975-1990 (pp. 7-19). Aix-enProvence : Université d'Aix-en-Provence.

Whitelaw, G. H. (2018). Konbini-Nation. The Rise of the Convenience Store in Post-Industrial Japan. In K. J. Cwiertka \& E. Machotka (Eds), Consuming Life in Post-Bubble Japan: A Transdisciplinary Perspective, Amsterdam, Amsterdam University Press, 69-88.

Wrigley, N., Branson, J., Murdock, A., \& Clarke, G. (2009). Extending the Competition Commission's findings on entry and exit of small stores in British high streets: implications for competition and planning policy. Environment and Planning A, 41, 2063-2085.

Wrigley, N., \& Dolega L. (2011). Resilience, fragility and adaptation: new evidence on the performance of UK high streets during global economic crisis and its policy implications. Environment and Planning A, 43, 2337-2363.

Wrigley, N., \& Lambiri, D. (2014). High Street Performance and Evolution. A Brief Guide to the Evidence. Southampton : University of Southampton. 
Yakushiji, T. 薬師寺 哲郎, \& Takahashi, K. 高橋 克也 (2013). Shokuryōhin no kaimono ni okeru fuben ya kurō to sono kaizen ni mukete no jūmin no ikō: daitoshikōgaidanchi, chihōtoshi, nōsanson ishikichōsa kara » 食料品の買い物における不便や苦労とその改善に向けての住民の意向 : 大都市郊外団地, 地方都市，農山村における意識調査から [Food Shopping Inconveniences and Problems and Local Residents' Approaches to Resolving Them: An Analysis of Residents' Consciousness in a Suburban Housing Complex in a Big City, a Small City Center, and a Farming Village], Nōson seikatsu kenkyū 農 村生活研究 [Journal of the Rural Life Society of Japan], 56, 2, 14-24.

Zukin, S., Kasinitz, P., \& Chen, X. (2015). Global cities, local streets, New-York : Routledge. 